\title{
ANALISIS SISTEM TRANSMISI PADA MESIN PEMINTAL BENANG DENGAN KAPASITAS 3 CONS
}

\author{
ELLYSA KUSUMA LAKSANAWATI ${ }^{1}$, ROFIROH ${ }^{2}$, SATRIA BAGUS SETIAWAN ${ }^{3}$ \\ Program Studi Teknik Mesin, Fakultas Teknik, Universitas Muhammadiyah Tangerang \\ Jl. Perintis Kemerdekaan I/33 Cikokol-Tangerang \\ E-Mail : ellysahendr@gmail.com
}

\begin{abstract}
ABSTRAK
Peningkatan kapasitas produksi telah menjadi tinjauan yang sangat penting dalam suatu industri. Maka sekarang perlu inovasi suatu konsep untuk mengembangkan dan memajukan industri kecil tersebut supaya hasil produksi gulungan benang semakin meningkat, dengan cara menciptakan suatu mesin penggulung benang yang lebih modern untuk menggantikan mesin penggulung benang yang masih tradisional. Dari sini timbul pemikiran suatu ide yaitu membuat suatu mesin penggulung benang dengan menggunakan tenaga motor listrik karena mesin dapat menggulung benang dengan cepat dan dengan mendapatkan hasil yang lebih baik. Poros motor listrik yang digunakan dikenai momen puntir (torsi) sebesar 0,68 (Nm). beban (W) yang bekerja pada poros motor listrik sebesar 113,66 N. Terdapat ukuran panjang pasak 4,23 (mm) dan 16,30 (mm). Diambil ukuran pasak 16,30 ( $\mathrm{mm})$, dengan alasan gaya akibat tekanan bidang lebih besar dibandingkan besarnya gaya yang akan memutuskan pasak. Pulli digerakkan sebesar 800 Rpm. Jenis sabuk disini adalah tipe A dengan ukuran lebar $12,5 \mathrm{~mm}$, tinggi $9 \mathrm{~mm}$ dan dengan sudut $2 \beta=40^{\circ}$. Jenis bahan sabuk adalah leather/kulit. Dengan demikian perencanaan sabuk dikatakan aman, karena $7,44 \mathrm{~m} / \mathrm{s}<30 \mathrm{~m} / \mathrm{s}$. Dari tabel tersebut didapat ukuran 1070,42 mm dengan standar nominal sabuk ukuran 41. Daya yang ditransmisikan oleh sabuk adalah 4078,26 Watt.
\end{abstract}

Kata Kunci : Motor Listrik, Benang, Mesin, Poros.

\begin{abstract}
Increasing production capacity has become a very important review in an industry. So now it is necessary to innovate a concept to develop and advance the small industry so that the production of yarn spools is increasing, by creating a more modern yarn winding machine to replace the traditional yarn winding machine. From this, an idea arose, namely to make a yarn winding machine using an electric motor because the machine can wind yarn quickly and with better results. The electric motor shaft used is subjected to a torsional moment (torque) of $0.68(\mathrm{Nm})$. the load $(\mathrm{W})$ acting on the electric motor shaft is $113.66 \mathrm{~N}$. There are lengths of pegs $4.23(\mathrm{~mm})$ and $16.30(\mathrm{~mm})$. A peg size of $16.30(\mathrm{~mm})$ was taken, on the grounds that the force due to the field pressure was greater than the magnitude of the force that would break the peg. The pulli is driven by 800 Rpm. The belt type here is type A with a width of $12.5 \mathrm{~mm}$, a height of $9 \mathrm{~mm}$ and an angle of $2 \mathrm{beta}=40^{\circ}$. The type of belt material is leather. Thus the design of the belt is said to be safe, because $7.44 \mathrm{~m} / \mathrm{s}$ $<30 \mathrm{~m} / \mathrm{s}$. From the table, it is obtained that the size is $1070.42 \mathrm{~mm}$ with the nominal standard of the belt size 41. The power transmitted by the belt is 4078.26 Watt.
\end{abstract}

Keywords: Electric Motor, Yarn, Machine, Shaft.

\section{PENDAHULUAN}

Dewasa ini perkembangan dan kemajuan teknologi mesin penggulung benang mengalami perkembangan sangat pesat. Pada industri - industri besar saat ini tidak sedikit yang menggunakan mesin penggulung benang. Hal ini sangat berkebalikan dengan industri kecil, para pengusaha penggulung benang industri kecil masih banyak yang menggunakan mesin penggulung benang manual, sehingga waktu yang dibutuhkan untuk memproduksi gulungan benang masih lama, dan hasil produksi yang masih belum maksimal mungkin, serta pengoperasian mesin tradisional yang masih belum fleksibel dan efektif.
Oleh karena itu dengan melihat berbagai potensi terhadap industri kecil penggulungan benang yang mempunyai peranan penting dalam menggerakan perekonomian para pengrajin penggulung benang di Indonesia. Maka sekarang ini perlu adanya inovasi suatu konsep untuk mengembangkan dan memajukan industri kecil tersebut supaya hasil produksi gulungan benang semakin meningkat tiap bulannya, dengan cara menciptakan suatu mesin penggulung benang yang lebih modern untuk menggantikan mesin penggulung benang yang masih tradisional.

Peningkatan kapasitas produksi telah menjadi tinjauan yang sangat penting dalam suatu industri. Dari sini timbul pemikiran suatu ide yaitu membuat 
suatu mesin penggulung benang dengan menggunakan tenaga motor listrik karena mesin dapat menggulung benang dengan cepat dan dengan mendapatkan hasil yang lebih baik, berbiaya operasional lebih murah, mudah dibawa, dan harga mesin relatif murah sehingga masyarakat dengan mudah bisa mendapatkannya.

Dalam menghadapi kenyataan diatas, maka penulis bermaksud merancang sebuah mesin pemintal benang. Mesin ini diharapkan bila melakukan pekerjaan menggulung benang tidak lagi menggunakan tenaga manual yang bisa membutuhkan tenaga dan waktu yang lama. Maka penulis mengambil judul "Analisis Sistem Transmisi Pada Mesin Pemintal Benang Dengan Kapasitas 3cons".

\section{METODOLOGI PENELITIAN}

Pemintalan tangan adalah industri rumahan yang penting di eropa abad pertengahan, tempat pemintal wol (paling sering wanita dan anak-anak) akan menyediakan benang yang cukup untuk melayani kebutuhan para pria yang mengoperasikan alat tenun, untuk dijual dalam sistem pemadam. Setelah penemuan kerangka air jenny pemintalan, permintaan sangat berkurang dengan mekanisasi. Teknologinya khusus dan mahal, dan menggunakan air sebagai tenaga penggerak. Berputar dan menenun ketika industri dipindahkan oleh pabrik khusus, yang dikembangkan oleh para industrialis dan investor mereka: industri pemintalan dan pertenunan, yang dulu tersebar luas, terkonsentrasi dimana sumber air, bahan baku, dan tenaga kerja tersedia, terutama Yorkshire barat. Pemerintah Inggris sangat protektif terhadap teknologi dan membatasi ekspornya. Setelah perang dunia 1, koloni tempat kapas ditanam mulai membeli dan memproduksi mesin pemintalan kapas dalam jumlah besar. Terobosan berikutnya adalah dengan pindah ke break atau open-end, spining, dengan kemudian adopsi serat buatan. Saat itu sebagian besar produksi telah pindah ke asia. Selama revolusi industri, pemintal, pengurai, dan penyapu dipekerjakaan di pabrik pemintalan dari abad ke-18 hingga ke-20.



Gambar 1. 1959 Lukisan Yang Menggambarkan Pekerja Tekstil Leiden

(Sumber:https://en.m.wikipedia.org/wiki/Spinning (textiles), 1/06/2020, 09:20)

Mesin Pemintal Benang Dengan Kapasitas 2 Cons



Gambar 2. Mesin pemintal dengan kapasitas 2 Cons
Keterangan:
1. Bonet
2. Besi Siku
3. Cons
4. Fillow Bearing

\section{Mesin Pemintal Benang Dengan Kapasitas 3 Cons}

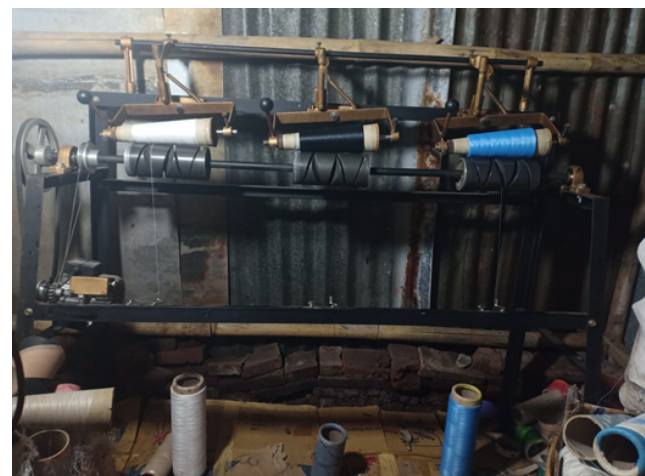

Gambar 3. Mesin Pemintal Benang dengan Kapasitas 3 Cons

Keterangan :

1. Bonet

2. shaft

3. Pulli yang digerakkan

4. V-belt

5. Pulli penggerak

6. Motor Listrik

7. Counter

8. Stang cons

9. Cons

10. Fillow Bearing

11. Besi Siku

12. Pengatur pengencang benang

13. Pengatur arah benang 


\section{Motor Listrik}

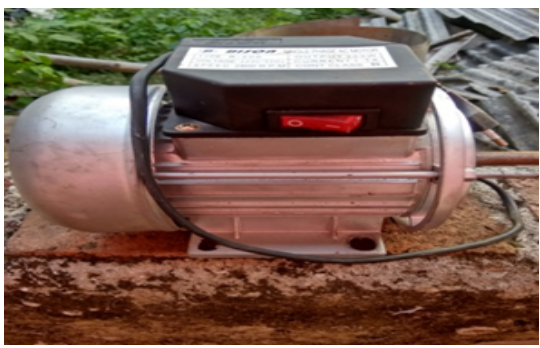

Gambar 4. Motor Listrik

Motor listrik yaitu mesin berputar yang bertujuan untuk mengubah daya listrik menjadi daya mekanik. Didalam motor listrik, konversi listrik menjadi daya mekanik terjadi pada bagian yang berputar pada mesin. Prinsip kerja listrik berdasarkan gejala bahwa suatu medan putar akan menimbulkan gaya gerak listrik pada penghantar yang berarus.

\section{HASIL DAN PEMBAHASAN}

Besar Nilai Torsi, Beban Poros, Dimensi Pasak Pada Mesin Pemintal Benang Dengan Kapasitas 2 Cons

Besar nilai dari torsi, beban poros dan dimensi pasak adalah sebagai berikut:

Motor Listrik. Poros motor terbuat dari bahan SC42, dengan tegangan tarik bahan poros $\left(\sigma_{\mathrm{B}}\right)$ sebesar 42 Mpa (Khurmi Gupta) dan tegangan geser bahan $\left(\tau_{\mathrm{B}}\right)$ sebesar $70 \mathrm{Mpa}$ (Khurmi Gupta). Dengan menggunakan persamaan torsi (momen puntir) yang bekerja pada poros motor tersebut adalah :

$\begin{array}{ll}\mathrm{P} \text { (daya) } & : 350 \mathrm{Watt} \\ \mathrm{N} \text { (putaran) } & : 1200 \mathrm{Rpm} \\ \mathrm{D} \text { (diameter poros motor) } & : 12 \mathrm{~mm} \\ \sigma_{\mathrm{B}} \text { (tegangan tarik bahan) } & : 42 \mathrm{Mpa} \\ \tau_{\mathrm{B}} \text { (tegangan geser) } & : 70 \mathrm{Mpa}\end{array}$

Sehingga,

$\mathrm{T}=\frac{60 . \mathrm{p}}{2 . \pi \cdot \mathrm{n}}=\frac{60 \times 350(\text { Watt })}{2 \times \pi \times 1200(\mathrm{Rpm})}=2,78 \mathrm{Nm}$

Dari perhitungan diatas dapat diketahui bahwa poros motor listrik yang digunakan pada mesin pemintal benang dengan kapasitas 2 cons ini dikenai momen puntir (torsi) sebesar 2,78 (Nm). Dari besarnya torsi yang bekerja pada poros motor listrik tersebut dapat dicari beban yang bekerja pada poros motor listrik tersebut yaitu:

$\mathrm{W}=\frac{\mathrm{T}}{\mathrm{r}}=\frac{2,78(\mathrm{Nm})}{0,006(\mathrm{~m})}=463,33 \mathrm{~N}$

Jadi beban (W) yang bekerja pada poros motor listrik sebesar 463,33 N
Pasak Pada Poros Motor Listrik. Pasak yang digunakan adalah jenis "pasak benam segiempat". Pasak inilah yang dipergunakan untuk menyambung antara poros motor listrik dan pulli. Berdasarkan ketentuan ukuran pasak (Khurmi Gupta), dimana untuk nilai $\mathrm{w}$ dan $\mathrm{t}$ adalah sebagai berikut:

$\mathrm{W}=\frac{\mathrm{d}}{4}=\frac{12 \mathrm{~mm}}{4}=3 \mathrm{~mm}$

Dengan perhitungan diatas didapat ketebalan pasak (w) adalah $3 \mathrm{~mm}$, tetapi untuk keamanan poros motor dan berdasakan tabel, maka dianjurkan ambil pasak berketebalan (b) $5 \mathrm{~mm}$. Dari tabel tersebut didapat juga untuk tinggi pasak (t) tersebut sebesar $5 \mathrm{~mm}$.

Dalam perencanaan, besar torsi yang terjadi pada poros harus lebih besar dari torsi yang dipindahkan. Analisis sebagai berikut:

1. Tegangan tarik bahan $\left(\sigma_{\mathrm{B}}\right): 42 \mathrm{Mpa}=42$ $\mathrm{N} / \mathrm{mm}^{2}$

2. Diameter poros motor (D) : $12 \mathrm{~mm}$

3. Torsi perencanaan (Tp) Nmm

$$
\mathrm{Tp}=\frac{\pi \sigma_{\mathrm{B}} \mathrm{D}^{3}}{16}=\frac{\pi \times 42\left(\frac{\mathrm{N}}{\mathrm{n}] \mathrm{m}^{2}}\right) \times 12^{3}\left(\mathrm{~mm}^{3}\right)}{16}=14,243 \mathrm{Nmm}
$$

Pada perencanaan pasak tersebut diatas, diperkirakan pada pasak tersebut akan terjadi 2 hal, yaitu :

a) Pasak akan putus terhadap gaya gesek

1. Dengan asumsi ini, maka pasak akan mengenai gaya keliling, ini terjadi karena poros berputar. Maka panjang pasak yang diperlukan adalah Tp :14,243 Nmm

2. Lebar pasak (b) $: 5 \mathrm{~mm}$

3. Tegangan geser $\left(\tau_{B}\right): 70 \mathrm{Mpa}=70 \mathrm{~N} / \mathrm{mm}^{2}$

$$
\begin{aligned}
& \mathrm{T}_{\mathrm{p}}=\mathrm{L} \text {. b. } \tau_{\mathrm{B}} \cdot \frac{\mathrm{d}}{2} \\
& \mathrm{~L}=\frac{2 \times 14,243(\mathrm{Nmm})}{8(\mathrm{~mm}) \times 70\left(\frac{\mathrm{N}}{\mathrm{m}^{2}}\right) \times 12(\mathrm{~mm})}=4,23 \mathrm{~mm}
\end{aligned}
$$

b) Pasak akan rusak akibat tekanan bidang. Berdasarkan asuransi tersebut, maka panjang pasak yang diperlukan adalah sebagai berikut:

$$
\begin{aligned}
& \mathrm{T}_{\mathrm{p}}=\mathrm{L} \cdot \frac{\mathrm{t}}{2} \cdot \sigma_{\mathrm{b}} \cdot \frac{\mathrm{d}}{2} \\
& \mathrm{~L}=\frac{4 \times 14,243(\mathrm{~mm})}{8(\mathrm{~mm}) \times 42\left(\frac{\mathrm{N}}{\mathrm{m}^{2}}\right) \times 10 \mathrm{~mm}}=16,30(\mathrm{~mm})
\end{aligned}
$$

Berdasarkan analisis panjang pasak pada point a dan b tersebut diatas, terdapat ukuran panjang pasak 4,23 $(\mathrm{mm})$ dan $16,30(\mathrm{~mm})$. Untuk proses perancangan ini, diambil ukuran pasak 16,30 (mm), dengan alasan gaya akibat tekanan bidang lebih besar dibandingkan besarnya gaya yang akan memutuskan pasak. 
Besar Diameter Pulli Digerakkan Dan Yang Digerakkan, Dan Ukuran V Belt Pada Mesin Pemintal Benang Dengan Kapasitas 2 Cons

Berikut ini adalah besarnya diameter pulli digerakkan dan yang digerakkan serta ukuran V Belt:

\section{Analisis Perencanaan Pulli}

Pada perencanaan pulli dan ketersedianya dipasaran, diambil ukuran pulli penggerak 50,8 mm sedangkan pulli yang digerakkan 76,2 $\mathrm{mm}$. Besarnya kecepatan dari puli yang digerakkan adalah sebagai berikut: $\mathrm{n}_{2}=\frac{1200 \mathrm{Rpm} \times 50,8 \mathrm{~mm}}{76,2 \mathrm{~mm}}=800 \mathrm{Rpm}$

Dengan demikian, didapat kecepatan akhir pulli digerakkan sebesar $800 \mathrm{Rpm}$.

\section{Analisis Perencanaan sabuk}

Pemilihan jenis sabuk disini adalah tipe A dengan ukuran lebar $12,5 \mathrm{~mm}$, tinggi $9 \mathrm{~mm}$ dan dengan sudut $2 \beta=40^{\circ}$. Jenis bahan sabuk adalah leather/kulit. Perancangan sabuk, terdapat beberapa kategori sebagai analisis, yaitu:

1. Kecepatan linier sabuk

$$
\begin{aligned}
\mathrm{v} & =\frac{\mathrm{pxd}_{1} \times \mathrm{n}_{1}}{60}=\frac{3,14 \times 50,8 \mathrm{~mm} \times 1200 \mathrm{Rpm}}{60}=3190 \frac{\mathrm{mm}}{\mathrm{s}} \\
& \cong 3,19 \frac{\mathrm{m}}{\mathrm{s}} .
\end{aligned}
$$

Adapun kecepatan liniear sabuk yang diizinkan adalah sebesar $30 \frac{\mathrm{m}}{\mathrm{s}}$ (Khurmi 1984). Dengan demikian perencanaan sabuk dikatakan aman, karena $3,19 \frac{\mathrm{m}}{\mathrm{s}}<30 \frac{\mathrm{m}}{\mathrm{s}}$.

2. Perhitungan kebutuhan panjang sabuk V (Vbelt)

Berdasarkan jari jari pulli yang digunakan serta jarak antara sumbu poros pulli penggerak dan yang digerakkan $240 \mathrm{~mm}$, maka kebutuhan panjang sabuk dapat dicari dengan menggunakan persamaan

$$
\begin{aligned}
\mathrm{L} & =\frac{\pi}{2} d_{2}+d_{1}+2 x+\frac{\left(d_{2}-d_{1}\right)^{2}}{4 x} \\
\mathrm{~L} & =\left[\frac{3,14}{2} \cdot(76,2+50,8)\right]+(2.240) \\
& +\left[\frac{(76,2-50,8)^{2}}{4.76,2}\right]=681,51 \mathrm{~mm}
\end{aligned}
$$

Berdasarkan ketersedian sabu/ belt dipasaran, maka hasil tersebut disesuaikan dengan tabel yang ada dipasaran. Dari tabel tersebut didapat ukuran $681,51 \mathrm{~mm}$ dengan standar nominal sabuk dipasaran adalah sabuk dengan nomor 27.

3. Tegangan sisi kendor $\left(T_{2}\right)$ dan sisi kencang $\left(T_{1}\right)$

a. Massa dari permeter sabuk adalah:

$$
\begin{aligned}
& \mathrm{m}=0,009 \mathrm{~m} \times 0,0125 \mathrm{~m} \times 1 \times 1000 \frac{\mathrm{kg}}{\mathrm{m}^{3}}=0,112 \\
& \text { b. } \frac{\mathrm{kg}}{\mathrm{m}} \\
& \text { Tegangan sentrifugal sabuk adalah: } \\
& \mathrm{Tc}=0,112 \frac{\mathrm{kg}}{\mathrm{m}} \times\left[3,19 \frac{\mathrm{m}}{\mathrm{s}}\right]^{2}=0,357 \mathrm{~N}
\end{aligned}
$$

c. Tekanan maksimum sabuk adalah:

$$
\mathrm{T}=\left[5 \frac{\mathrm{N}}{\mathrm{mm}^{2}}\right] \times[9 \mathrm{~mm} \times 12,5 \mathrm{~mm}]=562,5 \mathrm{~N}
$$

d. Tegangan sisi kencang sabuk adalah:

$T_{1}=562,5 \mathrm{~N}-0,357 \mathrm{~N}=562,1 \mathrm{~N}$

e. Tegangan sisi kendor sabuk adalah:

$$
\begin{aligned}
\sin \alpha & =\frac{38,1 \mathrm{~mm}-25,4 \mathrm{~mm}}{240 \mathrm{~mm}}=0,38 \text { maka } \\
\alpha & =22,33^{\circ} \\
\theta & =180^{\circ}-\left(2 \times 22,33^{\circ}\right)=135,34^{\circ} \\
& \cong 135,34^{\circ} \times \frac{\pi}{180^{\circ}}=2,36 \mathrm{rad}
\end{aligned}
$$

Analisis yang terjadi adalah sebagai berikut:

$$
\begin{aligned}
\log \left[\frac{T_{1}}{T_{2}}\right] & =0,25 \times 2,36 \mathrm{rad} \times \operatorname{cosec} 20^{\circ} \\
& =3,3 \text { maka }\left[\frac{T_{1}}{T_{2}}\right]=199 \\
T_{2} & =\frac{561,6}{199}=2,82
\end{aligned}
$$

f. Daya yang ditransmisikan oleh sabuk adalah:

$$
\begin{aligned}
& \mathrm{P}=\left(T_{1}-T_{2}\right) \cdot \mathrm{v} \\
& =(561,6-2,82) \times 3,19 \frac{\mathrm{m}}{\mathrm{s}} \\
& =1782,50 \text { watt }
\end{aligned}
$$

\section{Besar Nilai Torsi, Beban Poros, Dimensi Pasak Pada Mesin Pemintal Benang Dengan Kapasitas 3 Cons}

Besar nilai dari torsi, beban poros dan dimensi pasak adalah sebagai berikut:

\section{Motor Listrik}

Poros motor terbuat dari bahan $\mathrm{SC} 42$, dengan tegangan tarik bahan poros $\left(\sigma_{\mathrm{B}}\right)$ sebesar $42 \mathrm{Mpa}$ (Khurmi Gupta) dan tegangan geser bahan $\left(\tau_{B}\right)$ sebesar 70 Mpa (Khurmi Gupta). Dengan menggunakan persamaan torsi (momen puntir) yang bekerja pada poros motor tersebut adalah :
$\mathrm{P}$ (daya)
: 200 Watt
$\mathrm{N}$ (putaran) : $2800 \mathrm{Rpm}$
$\mathrm{D}$ (diameter poros motor) : $12 \mathrm{~mm}$
$\sigma_{\mathrm{B}}$ (tegangan tarik bahan) : $42 \mathrm{Mpa}$
$\tau_{\mathrm{B}}$ (tegangan geser) $: 70 \mathrm{Mpa}$

Dari perhitungan diatas dapat diketahui bahwa poros motor listrik yang digunakan pada mesin pemintal benang dengan kapasitas 2 cons ini dikenai momen puntir (torsi) sebesar 0,68 (Nm). Dari besarnya torsi yang bekerja pada poros motor listrik tersebut dapat dicari beban yang bekerja pada poros motor listrik tersebut yaitu:

$\mathrm{W}=\frac{\mathrm{T}}{\mathrm{r}}=\frac{0,68(\mathrm{Nm})}{0,006(\mathrm{~m})}=113,66 \mathrm{~N}$

Jadi beban (W) yang bekerja pada poros motor listrik sebesar 113,66 N 


\section{Pasak Pada Poros Motor Listrik}

Pasak yang digunakan adalah jenis "pasak benam segiempat". Pasak inilah yang dipergunakan untuk menyambung antara poros motor listrik dan pulli. Berdasarkan ketentuan ukuran pasak (Khurmi Gupta), dimana untuk nilai $\mathrm{w}$ dan $\mathrm{t}$ adalah sebagai berikut:

$\mathrm{W}=\frac{\mathrm{d}}{4}=\frac{12 \mathrm{~mm}}{4}=3 \mathrm{~mm}$

Dengan perhitungan diatas didapat ketebalan pasak (w) adalah $3 \mathrm{~mm}$, tetapi untuk keamanan poros motor dan berdasakan tabel, maka dianjurkan ambil pasak berketebalan (b) $5 \mathrm{~mm}$. Dari tabel tersebut didapat juga untuk tinggi pasak (t) tersebut sebesar $5 \mathrm{~mm}$.

Dalam perencanaan, besar torsi yang terjadi pada poros harus lebih besar dari torsi yang dipindahkan. Analisis sebagai berikut:

1. Tegangan tarik bahan $\left(\sigma_{\mathrm{B}}\right) \quad: 42 \mathrm{Mpa}=42 \mathrm{~N} / \mathrm{mm}^{2}$

2. Diameter poros motor (D) : $12 \mathrm{~mm}$

3. Torsi perencanaan (Tp) $\mathrm{Nmm}$

$$
\mathrm{Tp}=\frac{\pi \sigma_{B} D^{3}}{16}=\frac{\pi \times 42\left(\frac{\mathrm{N}}{\mathrm{n}] \mathrm{m}^{2}}\right) \times 12^{3}\left(\mathrm{~mm}^{3}\right)}{16}=14,243
$$

$\mathrm{Nmm}$

Pada perencanaan pasak tersebut diatas, diperkirakan pada pasak tersebut akan terjadi 2 hal, yaitu :

(1) Pasak akan putus terhadap gaya gesek . Dengan asumsi ini, maka pasak akan mengenai gaya keliling, ini terjadi karena poros berputar. Maka panjang pasak yang diperlukan adalah sebagai berikut:

$$
\begin{array}{ll}
\text { Tp } & : 14,243 \mathrm{Nmm} \\
\text { Lebar pasak }(\mathrm{b}) & : 5 \mathrm{~mm} \\
\text { Tegangan geser }\left(\tau_{\mathrm{B}}\right) & : 70 \mathrm{Mpa}=70 \mathrm{~N} / \mathrm{mm}^{2} \\
\mathrm{~T}_{\mathrm{p}}=\mathrm{L} \cdot \mathrm{b} . \tau_{\mathrm{B}} \cdot \frac{\mathrm{d}}{2} & \\
\mathrm{~L}=\frac{2 \times 14,243(\mathrm{Nmm})}{8(\mathrm{~mm}) \times 70\left(\frac{\mathrm{N}}{\mathrm{m}^{2}}\right) \times 12(\mathrm{~mm})}=4,23 \mathrm{~mm}
\end{array}
$$

Maka panjang pasak yang terjadi akibat tekanan gesek adalah sebesar 4,23 (mm)

(2) Pasak akan rusak akibat tekanan bidang.

Berdasarkan asuransi tersebut, maka panjang pasak yang diperlukan adalah sebagai berikut:

$$
\begin{aligned}
& \mathrm{T}_{\mathrm{p}}=\mathrm{L} \cdot \frac{\mathrm{t}}{2} \cdot \sigma_{\mathrm{b}} \cdot \frac{\mathrm{d}}{2} \\
& \mathrm{~L}=\frac{4 \times 14,243(\mathrm{~mm})}{8(\mathrm{~mm}) \times 42\left(\frac{\mathrm{N}}{\mathrm{m}^{2}}\right) \times 10 \mathrm{~mm}}=16,30 \mathrm{~mm}
\end{aligned}
$$

Berdasarkan analisis panjang pasak pada point a dan b tersebut diatas, terdapat ukuran panjang pasak 4,23 ( $\mathrm{mm})$ dan 16,30 $(\mathrm{mm})$. Untuk proses perancangan ini, diambil ukuran pasak 16,30 (mm), dengan alasan gaya akibat tekanan bidang lebih besar dibandingkan besarnya gaya yang akan memutuskan pasak.

\section{Besar Diameter Pulli Digerakkan Dan Yang Digerakkan, Dan Ukuran V Belt Pada Mesin Pemintal Benang Dengan Kapasitas 3 Cons}

Berikut ini adalah besarnya diameter pulli digerakkan dan yang digerakkan serta ukuran V Belt:

\section{Analisis Perencanaan Pulli}

Pada perencanaan pulli dan ketersedianya dipasaran, diambil ukuran pulli penggerak 50,8 mm sedangkan pulli yang digerakkan $177,8 \mathrm{~mm}$. Besarnya kecepatan dari puli yang digerakkan adalah sebagai berikut:

$\mathrm{n}_{2}=\frac{2800 \mathrm{Rpm} \times 50,8 \mathrm{~mm}}{177,8 \mathrm{~mm}}=800 \mathrm{Rpm}$

Dengan demikian, didapat kecepatan akhir pulli digerakkan sebesar 800 Rpm.

\section{Analisis Perencanaan sabuk}

Pemilihan jenis sabuk disini adalah tipe A dengan ukuran lebar 12,5 $\mathrm{mm}$, tinggi $9 \mathrm{~mm}$ dan dengan sudut $2 \beta=40^{\circ}$. Jenis bahan sabuk adalah leather $/$ kulit. Perancangan sabuk, terdapat beberapa kategori sebagai analisis, yaitu:

(1) Kecepatan linier sabuk

$$
\mathrm{v}=\frac{\mathrm{pxd}_{1} \mathrm{xn}_{1}}{60}
$$

$\mathrm{v}=\frac{3,14 \times 50,8 \mathrm{~mm} \times 2800 \mathrm{Rpm}}{60}=7443 \frac{\mathrm{mm}}{\mathrm{s}} \cong 7,44 \frac{\mathrm{m}}{\mathrm{s}}$ Adapun kecepatan liniear sabuk yang diizinkan adalah sebesar $30 \frac{\mathrm{m}}{\mathrm{s}}$ (Khurmi 1984). Dengan demikian perencanaan sabuk dikatakan aman, karena $7,44 \frac{\mathrm{m}}{\mathrm{s}}<30 \frac{\mathrm{m}}{\mathrm{s}}$.

(2) Perhitungan kebutuhan panjang sabuk V (Vbelt)

Berdasarkan jari jari pulli yang digunakan serta jarak antara sumbu poros pulli penggerak dan yang digerakkan $350 \mathrm{~mm}$, dengan menggunakan persamaan

$\mathrm{L}=\frac{\pi}{2} d_{2}+d_{1}+2 x+\frac{\left(d_{2}-d_{1}\right)^{2}}{4 x}$

$\mathrm{L}=\left[\frac{3,14}{2} \cdot(177,8+50,8)\right]+(2$. 350) + $\left[\frac{(177,8-50,8)^{2}}{4.350}\right]=1070,42 \mathrm{~mm}$

Berdasarkan ketersedian sabu/belt dipasaran, maka hasil tersebut disesuaikan dengan tabel yang ada dipasaran. Dari tabel tersebut didapat ukuran 1070,42 mm dengan standar nominal sabuk dipasaran adalah sabuk dengan nomor 42 .

(3) Tegangan sisi kendor $\left(T_{2}\right)$ dan sisi kencang $\left(T_{1}\right)$

Massa dari permeter sabuk adalah:

$\mathrm{m}=0,009 \mathrm{~m} \times 0,0125 \mathrm{~m} \times 1 \times 1000 \frac{\mathrm{kg}}{\mathrm{m}^{3}}=0,112 \frac{\mathrm{kg}}{\mathrm{m}}$

Tegangan sentrifugal sabuk adalah:

$\mathrm{Tc}=0,112 \frac{\mathrm{kg}}{\mathrm{m}} \times\left[7,44 \frac{\mathrm{m}}{\mathrm{s}}\right]^{2}=0,833 \mathrm{~N}$ 
Tekanan maksimum sabuk adalah: $\mathrm{T}=\left[5 \frac{\mathrm{N}}{\mathrm{mm}^{2}}\right] \times[9 \mathrm{~mm} \times 12,5 \mathrm{~mm}]=562,5 \mathrm{~N}$ Tegangan sisi kencang sabuk adalah:

$T_{1}=562,5 \mathrm{~N}-0,833 \mathrm{~N}=561,6 \mathrm{~N}$

Tegangan sisi kendor sabuk adalah:

$\sin \alpha=\frac{88,9 \mathrm{~mm}-25,4 \mathrm{~mm}}{350 \mathrm{~mm}}=0,18$ maka $\alpha=10,36^{\circ}$

$\theta=180^{\circ}-\left(2 \times 10,36^{\circ}\right)=159,28^{\circ} \cong$

$159,28^{\circ} \times \frac{\pi}{180^{\circ}}=2,78 \mathrm{rad}$

Analisis yang terjadi adalah sebagai berikut:

$$
\begin{aligned}
\log \left[\frac{T_{1}}{T_{2}}\right] & =0,25 \times 2,78 \mathrm{rad} \times \operatorname{cosec} 20^{\circ} \\
\log \left[\frac{T_{1}}{T_{2}}\right] & =2,1 \mathrm{maka}\left[\frac{T_{1}}{T_{2}}\right]=126 \\
T_{2} & =\frac{561,6}{126}=4,46
\end{aligned}
$$

(4) Daya yang ditransmisikan oleh sabuk adalah: $\mathrm{P}=\left(T_{1}-T_{2}\right) \cdot \mathrm{v}=(561,6-4,46) \times 7,32 \frac{\mathrm{m}}{\mathrm{s}}=$ 4078,26 watt

\section{Analisis Perhitungan Pada Mesin Pemintal Benang Dengan Kapasitas 2 Cons}

Adapun hasil analisis perhitungan pada mesin pemintal benang dengan kapasitas 3 cons adalah sebagai berikut:

Tabel 1. Transmisi pemintal benang 2 cons

\begin{tabular}{|c|l|l|}
\hline No & \multicolumn{1}{|c|}{ Transmisi Mesin Pemintal Benang 2 Cons } & \multicolumn{1}{|c|}{ Hasil Perhitungan } \\
\hline 1 & Nïlai Torsi & 2,78 Nm \\
\hline 2 & Beban Yang Bekeria Pada Poros Motor Listrik & $463,33 \mathrm{~N}$ \\
\hline 3 & Ketebalan Pasak & $3 \mathrm{~mm}$ \\
\hline 4 & Panjang Pasak & $4,23 \mathrm{~mm}$ \\
\hline 5 & Kecepatan Pulli Yang digerakkan & $800 \mathrm{Rpm}$ \\
\hline 6 & Ukuran Sabuk (V - Belt) & $681,51 \mathrm{~mm}$ Tipe A 27 \\
\hline 7 & Daya Yang Ditransmisikan Sabuk & 1782,50 Watt \\
\hline
\end{tabular}

Dari perhitungan diatas dapat diketahui bahwa poros motor listrik yang digunakan pada mesin pemintal benang dengan kapasitas 2 Cons ini dikenai momen puntir (torsi) sebesar 2,78 (Nm). Dari besarnya torsi yang bekerja pada poros motor listrik tersebut dapat dicari beban yang bekerja pada poros motor listrik tersebut yaitu 463,33 N. Dengan perhitungan diatas didapat ketebalan pasak (w) adalah $3 \mathrm{~mm}$. Berdasarkan analisis panjang pasak pada point $a$ dan $b$ tersebut diatas, terdapat ukuran panjang pasak 4,23 (mm) dan 16,30 (mm). Untuk proses perancangan ini, diambil ukuran pasak 16,30 (mm), dengan alasan gaya akibat tekanan bidang lebih besar dibandingkan besarnya gaya yang akan memutuskan pasak. Dengan demikian, didapat kecepatan akhir pulli digerakkan sebesar 800 Rpm. Berdasarkan ketersedian sabu/ belt dipasaran, maka hasil tersebut disesuaikan dengan tabel yang ada dipasaran. Dari tabel tersebut didapat ukuran
$681,51 \mathrm{~mm}$ dengan standar nominal sabuk dipasaran adalah sabuk dengan nomor 27. Daya yang ditransmisikan oleh sabuk adalah 1782,50 watt.

\section{Analisis Perhitungan Pada Mesin Pemintal Benang Dengan Kapasitas 3 Cons}

Adapun hasil analisis perhitungan pada mesin pemintal benang dengan kapasitas 3 cons adalah sebagai berikut:

Tabel 2. Transmisi pemintal benang 3 cons

\begin{tabular}{|c|l|l|}
\hline$N_{0}$ & \multicolumn{1}{|c|}{ Transmisi Mesin Pemintal Benang 3 Cons } & \multicolumn{1}{|c|}{ Hasil Perhitungan } \\
\hline 1 & Nilai Torsi & $0,68 \mathrm{Nm}$ \\
\hline 2 & Bebann Yang Bekerja Pada Poros Motor Listrik & $113,66 \mathrm{~N}$ \\
\hline 3 & Ketebalan Pasak & $3 \mathrm{~mm}$ \\
\hline 4 & Panjang Pasak & $4,23 \mathrm{~mm}$ \\
\hline 5 & Kecepatan Pulli Yang digerakkan & 800 Rpm \\
\hline 6 & Ukuran Sabuk ( V - Belt ) & $1070,42 \mathrm{~mm}$ Tipe A 42 \\
\hline 7 & Daya Yang Ditrannsmiskan Sabuk & 4078,26 Watt \\
\hline
\end{tabular}

Dari perhitungan diatas dapat diketahui bahwa poros motor listrik yang digunakan pada mesin pemintal benang dengan kapasitas 3 cons ini dikenai momen puntir (torsi) sebesar 0,68 (Nm). Dari besarnya torsi yang bekerja pada poros motor listrik tersebut dapat dicari beban yang bekerja pada poros motor listrik tersebut yaitu 113,66 N. Dengan perhitungan diatas didapat ketebalan pasak (w) adalah $3 \mathrm{~mm}$. Berdasarkan analisis panjang pasak pada point $a$ dan $b$ tersebut diatas, terdapat ukuran panjang pasak 4,23 (mm) dan 16,30 (mm). Untuk proses perancangan ini, diambil ukuran pasak 16,30 (mm), dengan alasan gaya akibat tekanan bidang lebih besar dibandingkan besarnya gaya yang akan memutuskan pasak. Dengan demikian, didapat kecepatan akhir pulli digerakkan sebesar $800 \mathrm{Rpm}$. Berdasarkan ketersedian sabu/ belt dipasaran, maka hasil tersebut disesuaikan dengan tabel yang ada dipasaran. Dari tabel tersebut didapat ukuran 1070,42 $\mathrm{mm}$ dengan standar nominal sabuk dipasaran adalah sabuk dengan nomor 42. Daya yang ditransmisikan oleh sabuk adalah 4078,26 watt.

\section{KESIMPULAN}

Dari hasil penelitian yang dilakukan dapat diambil kesimpulan sebagai berikut:

1. Dari perhitungan diatas dapat diketahui bahwa poros motor listrik yang digunakan pada mesin pemintal benang dengan kapasitas 3 cons ini dikenai momen puntir (torsi) sebesar 0,68 (Nm). beban (W) yang bekerja pada poros motor listrik sebesar 113,66 N. Berdasarkan analisa panjang 
pasak pada point a dan $\mathrm{b}$ tersebut diatas, terdapat ukuran panjang pasak 4,23 (mm) dan 16,30 $(\mathrm{mm})$. Untuk proses perancangan ini, diambil ukuran pasak 16,30 (mm), dengan alasan gaya akibat tekanan bidang lebih besar dibandingkan besarnya gaya yang akan memutuskan pasak.

2. Didapatkan kecepatan akhir pulli digerakkan sebesar $800 \mathrm{Rpm}$. Pemilihan jenis sabuk disini adalah tipe A dengan ukuran lebar 12,5 $\mathrm{mm}$, tinggi $9 \mathrm{~mm}$ dan dengan sudut $2 \beta=$ $40^{\circ}$. Jenis bahan sabuk adalah leather/kulit. Adapun kecepatan liniear sabuk yang diizinkan adalah sebesar $30 \frac{\mathrm{m}}{\mathrm{s}}$ (Khurmi 1984). Dengan demikian perencanaan sabuk dikatakan aman, karena $7,44 \frac{\mathrm{m}}{\mathrm{s}}<30 \frac{\mathrm{m}}{\mathrm{s}}$. Berdasarkan ketersedian sabu/ belt dipasaran, maka hasil tersebut disesuaikan dengan tabel yang ada dipasaran. Dari tabel tersebut didapat ukuran 1070,42 mm dengan standar nominal sabuk dipasaran adalah sabuk dengan nomor 42. Daya yang ditransmisikan oleh sabuk adalah 4078,26 Watt.

\section{DAFTAR PUSTAKA}

Abdul Khoir, 2018, Analisa Perancangan Sistem Transmisi Pada Alat Pemotong Kentang Mustopa Kapasitas $15 \mathrm{Kg} / \mathrm{Jam}$, Skripsi, Jurusan Teknik Mesin Fakultas Teknik, Tangerang.

Agus Nurjaman, Zaenal Abidin. Analisis Mesin Pemutar Es Krim Dengan Sistem Control Timer. Jurnal Media Teknologi, Vol. 06 No. 01 Agustus 2019.

Gugun Gundara, Slamet Riyadi. Rancang Bangun Mesin Parut Kelapa Skala Rumah Tangga Dengan Motor Listrik 220 Volt. Jurnal Teknik Mesin Universitas Muhammadiyah Metro, Vol. 6 No. 1. 2017. p-ISSN: 23016663, e-ISSN: 2477-250X.

Irdam, Dani Setiawan, Fransiskus Odi, Sri Rahayu, W.K. Rancang bangun mesin penyuwir daging untuk bahan baku abon. Jurnal ilmiah teknik mesin, Vol. 10, no. 1, November 2018, ISSN : 2085-8817.

Khurmi, R, S., Gupta, J, K, Machine Design. Eurasia Publising House, New Delhi, 2005.

Langgie Janu Hirandhi, Bambang Sugiyantoro, Harnoko. Pengaruh Jumlah Kutub Pada Model Motor Induksi Dengan Supply Satu
Fase. Jurnal Penelitian Teknik Elektro, Vol. 3 No.4 Desember 2010.

Rahmat Cahyono, Dody Yulianto, Syawaldi. Perancangan Mesin Pengaduk Tepung Tipe Horizontal Dengan Menggunakan Motor Listrik Sebagai Penggerak. Journal Renewable Energy \& Mechanics (REM), Vol.01 No.02 2018:48-67, E-ISSN: 26148315.

Ryan Rinaldi, 2018, Analisa Sistem Transmisi Pulley Dan V-Belt Terhadap Turbin Pelton Dalam Menghasilkan Listrik Skala Laboratorium Berkapasitas 50 Watt, Skripsi, Jurusan Teknik Mesin Fakultas Teknik, Tangerang.

Samhuddin, Muhammad Hasbi, Jamiludin. Perencanaan Sistem Transmisi Alat Peniris Pada Mesin Pengering Helm. Jurnal Ilmiah Mahasiswa Teknik Mesin, Vol. 3, No. 1, Maret 2018, e-ISSN: 2502-8944.

Sri Endah Susilowati. Desain Kopling Untuk Mesin Diesel Daihatsu 6DLM-24. Jurnal Kajian Teknologi, Vol. 10 Nomor 2 Juli 2014. 